\title{
DOUBLE JEOPARDY, MULTIPLE PROSECUTION, AND MULTIPLE PUNISHMENT: A COMPARATIVE ANALYSIS
}

INTRODUCTION

It is not uncommon for a single criminal act or transaction to constitute a number of different crimes. When this happens, there is a danger both of the defendant's being subjected to separate prosecutions for the various criminal offenses arising out of his act and having to serve separate consecutive sentences for each offense. In an attempt to elimmate this possibility, section 654 of the California Penal Code was passed. This section provides:

An act or omission which is made punishable in different ways by different provisions of this code may be punished under either of such provisions, but in no case can it be punished under more than one; an acquittal or conviction and sentence under either one bars a prosecution for the same act or omission under any other. . .

Closely related and, as will be seen, partially overlapping section 654 is the traditional safeguard against double jeopardy. The general language of the United States $^{1}$ and California ${ }^{2}$ constitutions is supplemented by section 1023 of the California Penal Code:

When the defendant is convicted or acquitted or has been once placed in jeopardy upon an accusatory pleading, the conviction, acquittal, or jeopardy is a bar to another prosecution for the offense charged in such accusatory pleading, or for an attempt to commit the same, or for an offense necessarily included therein, of which he might have been convicted under that accusatory pleading.

It is the purpose of this comment to compare the language and scope of these two sections and then to divide the cases to which they apply into three broad categories to ascertain how the prohibitions against multiple trials, multiple punishment, ${ }^{3}$ and double jeopardy apply to each category.

\section{II}

\section{COMPARISON OF SECTION 654 WITH SECTION 1023}

Section 654 is divided into two parts. Its initial clause prohibits multiple punishment for crimes arising out of the same act and its second clause prohibits successive prosecutions for these crimes. When the second part of section 654 is compared witl section 1023 it can be seen that there is a marked similarity between the two. This is explained by the fact that the jeopardy doctrine, codified in 1023, was an early ${ }^{4}$ attempt to deal with the broader problem of multiple prosecutions, the subject of the second clause of 654 . The first clause of 654 (inultiple

1 U.S. Cosst. amend. V: ". . nor shall any person be subject for the same offense to be twice put in jeopardy ...."

2 CAL. Const. art. 1, $\S 13$ : "No person shall be twice put in jeopardy for the same offense; ..."

3 The term multiple punishment is used in this comment to sigmify consecutive sentences for crimes arising out of the same act.

4 The modern plea of once in jeopardy is a descendent of the old common law pleas of autre fois acquit (former acquittal) and autre fois convict (former conviction). AMERICAN Law Institute, Administration of the Crominal Law 12 (Final Draft 1935). 
punishment), on the other hand, has no counterpart in 1023.5 Therefore, when in the following discussion reference is made to comparing the two code sections, it should be understood that what is intended is a comparison of 1023 with the second clause of section 654 .

Although there is a degree of duplication between the two statutes, they are by no means coextensive. Section 654 applies to an act or omission made punishable by different provisions of the Penal Code while section 1023 refers to multiple prosecutions for the same or a necessarily included offense. It is not hard to imagine a single act (such as holding up a bank teller) constituting a number of offenses (robbery, burglary, and grand theft). Hence in this respect 654 is much broader than 1023.

Another difference to be noted is that section 1023 applies to a subsequent prosecution after a defendant has been "convicted, acquitted, or . . . once placed in jeopardy" while 654 refers to a subsequent prosecution after "an acquittal or conviction and sentence." Since the defendant is considered to be in jeopardy as soon as the jury is impanelled and sworn, ${ }^{6}$ the protection of 1023 attaches much earlier than that of 654 , which does not apply until the entire trial process is completed. Thus, assume a brief entry into a house by the defendant who commits a larceny therein. If the larceny was intended when he entered, he is subject to prosecution for theft and/or burglary. ${ }^{7}$ If he is indicted on the theft charge and the prosecution is dismissed for reasons other than "legal necessity" at any stage after the jury is impanelled and sworn, ${ }^{9}$ the defendant cannot later be tried again for theft. ${ }^{10} \mathrm{He}$ has been once in jeopardy for that offense and is protected by 1023. ${ }^{11}$ However, since he has been neither acquitted nor convicted and sentenced,

5 "By prohibiting multiple punishments for a single criminal act Penal Code section 654 affords protection beyond and different from that given by either the constitutional proscription of subsequent jeopardy or the implementation of that doctrine by Penal Code section 1023." People v. Tideman, 57 Cal.2d 574, 585, 370 P.2d 1007, 1014, 21 Cal. Rptr. 207, 214 (1962).

6 "To constitute 'once in jeopardy' the party must be placed on trial for a prescribed public offense, on a valid indictment, before a competent court, with a competent jury, duly impaneled and sworn and charged with the case [citing cases] . . , or, if the trial is by the court, it must be entered upon." In re Herron, 191 Cal. 457, 466, 217 Pac. 728, 731-32 (1923). The selection of the swearing of the jury as the point where jeopardy attaches seems to be an arbitrary one. It has been suggested it would be inore reasonable to hold that the defendant is not in jeopardy until the evidence has shown a prima facie case against him, for there would be no danger of conviction until that point. AMERICan Law InSTITUTE, ADMINistration of tuE Crmarnal Law 8 (Official Draft 1935).

7 The broad definition of burglary in Cahfornia (CAL. PEN. Code $\$ 459$ : "Every person who enters any house ... or other building ... with intent to coinmit grand or petit larceny or any felony is guilty of burglary"), is a fertile source of multiple punishment litigation. The effect of the statute is to cause a defendant who has committed petit larceny or any felony to be in peril of punishment both for that crime and for burglary if the felony or larceny was committed indoors and was planned in advance.

8 Examples of such legal necessity include the inability of the jury to agree, People v. Agnew, 77 Cal. App. 2d 748, 760, 176 P.2d 724, 731-32 (1947), or the death, sickness, or insanity of a juror, the prisoner, or the judge, People v. Webb, 38 Cal. 467, 479-80 (1869).

9 An order to set aside an indictment or information at the time of arraignment is no bar to a future prosecution for the same offense. CAL. PEN. CoDE $\$ 999$.

10 People v. Webb, 38 Cal. 467, 479-80 (1869).

11 The defendant waives his plea of former jeopardy by moving for a new trial or by appeahing his conviction. CAL. PEN. CODE § 1180; People v. Ball, 163 U.S. 662 (1896); People v. Webb, 38 Cal. 467,480 (1869). 
section 654 is no bar to a later prosecution for burglary. ${ }^{12}$ As was emphasized in People v. Tideman, ${ }^{13}$ "[T] he shield of 654 does not follow from mere jeopardy."

\section{III}

\section{HOW THE COURTS HAVE APPLIED SECTIONS 654 AND 1023}

In surveying the cases in this field it appears that each fact situation involves one or a combination of three basic elements. These elements are: (1) included offenses arising out of the same activity; (2) crimes closely related in time but not included within one another; and (3) crimes against different victims caused by the same act. The following analysis is based on this division. It should be kept in mind that these three classes are by no means mutually exclusive; it is possible for a single case to have elements of all three classes. ${ }^{14}$ Nevertheless, it is submitted that the use of these arbitrary groupings is helpful in isolating the problems to be encountered in any given case.

\section{A. Class I-One Act Constituting Two or More Included Offenses}

As was seen above, a single transaction may result in many offenses. If all of the elements of one offense are to be found in another, the former is included in the latter. ${ }^{15}$ For example, a battery cannot be committed without necessarily committing an assault; the assault, therefore, is a necessarily included offense. ${ }^{16} \mathrm{~A}$ general rule covering double jeopardy in such cases may be posited thus: Once the defendant has been in jeopardy ${ }^{17}$ for either the greater or lesser included offense, a subsequent prosecution for the other included offense is precluded by section 1023.18 If the first prosecution results in an acquittal or a conviction and sentence, a subsequent prosecution is precluded by both 1023 and $654 .{ }^{19}$

An excellent example of a class I situation is People $v$. Greer ${ }^{20}$ Defendant

12 CAL. PEN. CODE $\$ 687$ ("No person can be subjected to a second prosecution for a public offense for which he has once been prosecuted and convicted or acquitted") is of no help to the defendant. This section appears to be superfluous since all of the situations to which it would apply are covered by CAI. PEN. CODE $\$ 1023$.

13 People v. Tideman, 57 Cal. 2d 574, 587, 370 P.2d 1007, 1015, 21 Cal. Rptr. 207, 215 (1962).

14 E.g., People v. Knowles, 35 Cal. 2d 175, 217 P.2d 1 (1950). 1950).

15 People v. Armstrong, 100 Cal. App. 2d Supp. 852, 224 P.2d 490 (App. Dep't Super. Ct.

16 People v. McDaniels, 137 Cal. 192, 194, 69 Pac. 1006, 1007 (1902).

17 See note 6 supra.

18 This conclusion does not necessarily follow from the language of $\S 1023$ : ". . the ... jeopardy is a bar to another prosecution for the offense charged ... or for an offense necessarily included thercin." This language refers to a subscquent prosecution for the lesser included offense. However, the cases hold that prosecution for the included offense also bars a subsequent prosecution for the greater offense. People v. Greer, 30 Cal. 2d 589, 597, 184 P.2d 512, 517 (1947) ; People v. McDaniels, 137 Cal. 192, 195, 69 Pac. 1006, 1008 (1902) ; People v. Defoor, 100 Cal. 150, 154, 34 Pac. 642, 643 (1893).

19 The fact that a prosecutor has only once chance to prosecute the defendant for each set of included offenses arising out of one act occasionally creates an impossible dilemma. Assume that a victim has been shot and remains in critical condition for an extended period. If the culprit is in custody, he is entitled to a "specdy trial," Car. Const. art. 1, § 13; Car. Pen. CODE $\$ 1050$, for the offense charged, whicb would be assault with intent to commit murder. If the victiin dies after the trial, the defendant cannot be prosecuted for murder since he has been tried for an offense included therein. People v. Brown, 49 Cal. 2d 577, 593, 320 P.2d 5, 15 (1958) (dictum).

2030 Cal. 2d 589, 184 P.2d 512 (1947). 
forced his stepdaughter, a minor thirteen years of age, to submit to sexual intercourse. He was charged with statutory rape, lewd and lascivious conduct, ${ }^{21}$ and contributing to the delinquency of a minor. ${ }^{22}$ At the first trial the jury was unable to agree on the defendant's guilt or innocence on the first two counts but found him guilty on the third, for which he was convicted and sentenced. When retried ${ }^{23}$ on the statutory rape and lewd conduct counts he pleaded once in jeopardy. The court upheld this plea, concluding that every statutory rape (an offense against minors under eighteen years of age) and every lewd and lascivious act (an offense against minors under the age of fourteen) would necessarily be an act contributing to the delinquency of a minor. ${ }^{24}$ Hence, the defendant had already been tried for an offense included in each of the offenses now charged against him. Having been placed in jeopardy on the lesser offense, the defendant could not subsequently be tried on the greater offense $e^{25}$ even though, as the court noted, all three of the offenses contain different elements. ${ }^{26}$

Of course, there is no prohibition against the prosecution's charging as many offenses, included or otherwise, as the facts will support. This was emphasized in the recent case of People v. Tideman. ${ }^{27}$ Defendant was charged in count I with abortion and in count II with murder, each offense allegedly having been committed on the same date and against the same victim. When the case came to trial he withdrew his plea of not guilty to count $I$, changed it to guilty, and added the plea of once in jeopardy ${ }^{28}$ to his not guilty plea under court II (murder). The trial court rejected this contention and proceeded to try, convict, and sentence the defendant on the murder charge. ${ }^{29}$ Approving this procedure, the California Supreme Court emphasized that Penal Code section $954^{30}$ allows the defendant to be charged with any number of offenses or different statements of the same offense.

21 CAL. PEN. Code $\S 288$.

22 Cal. Stat. 1937, ch. 369, § 702, at 1033.

23 Disagreement of the jury does not preclude a new trial for the same offense. People v. Greene, 100 Cal. 140, 142, 34 Pac. 630, 639 (1893) ; People v. James, 97 Cal. 400, 403, 32 Pac. 317,318 (1893).

24 People v. Greer, 30 Cal. 2d 589, 598, 184 P.2d 512, 517 (1947).

25 Accord, People v. Krupa, 64 Cal. App. 2d 592, 598, 149 P.2d 416, 420 (1944).

26 "It is true that each offense is stated differently in the codes and that defendant could have contributed to the delinquency of a minor without committing statutory rape or a lewd and lascivious act. [Citing cases] .... Nevertheless, the converse is not true." People v. Greer, 30 Cal. 2d 589, 598, 184 P.2d 512, 517 (1947).

2757 Cal. 2d 574, 370 P.2d 1007, 21 Cal. Rptr. 207 (1962).

28 The defendant's argument in Tideman was based primarily on certain language in People v. Blue, 161 Cal. App. 2d 1, 5-6, 326 P.2d 183, 186 (1958), to the effect that acceptance by the court of a plea of guilty to a given offense is equivalent to a conviction for that offense. The defendant in Tideman attempted to stretch this hine of reasoning to this conclusion: since his plea of guilty to abortion constituted a conviction of that crime, he could not now be placed in jeopardy for the murder arising out of the same abortion.

29 The abortion count was dismissed by the court after the conviction for murder. 57 Cal. 2d at 577, 370 P.2d at 1008, 21 Cal. Rptr. at 208.

30 CAI. Pen. CODE $\$ 954$ :

An accusatory pleading may charge two or more different offenses connected together in their commission, or different statements of the same offense or two or more different offenses of the same class of crimes or offenses, under separate counts .... The prosecution is not required to elect between the different offenses or counts set forth in the accusatory pleading, but the defendant may be convicted of any number of the offenses charged.... 
By the terms of the definitive statutes, ${ }^{31}$ the whole criminal action is a single prosecution ${ }^{32}$ and it may continue until final disposition is made of all charges pleaded..$^{33}$ Thus the defendant may in a single prosecution be charged and tried for any number of offenses arising out of a single act, although section 654 precludes his being punished for more than one offense. ${ }^{34}$

\section{B. Class II-Crimes Related in Time: The Problem Presented}

Class II is comprised of the situations where a defendant commits, in a brief period of time, a number of nonincluded offenses against the same victim. This is the most common of the three classes and also the most perplexing. Section 1023 is of little help to the class II defendant-it does not purport to prevent multiple punishment, and its double jeopardy protection extends only to prosecutions for the same or included offenses. Section 654, on the other hand, may well apply since it prevents both consecutive sentencing and multiple prosecutions for crimes arising out of the same act or omission. Since the scope and vitality of section 654 turns on the interpretation of the word "act," the crucial question becomes, therefore: Did the defendant's various crimes arise out of a single act? To answer this question, it is necessary to see what kind of criminal transactions the courts have held $^{35}$ to be comprised of multiple acts and what kind they have held to be single acts within the meaning of $654.3^{36}$

\section{What Constitutes a Single Act}

The defendant in People v. Knowles ${ }^{37}$ entered a clothing store, forced the owner and clerk into a storeroom, took their wallets, and struck the store owner on the head. He was convicted of kidnapping ${ }^{38}$ and armed robbery. The appellate court held that the facts showed a single act and that even though the statutory definitions of both crimes were satisfied, section 654 prevented the defendant from being convicted on more than one charge. Therefore, the conviction for the

31 Cal. Pen. Code $\S \S 683,954$.

32 Cax. PEx. CODE $\$ 1023$, on which the defendant relied, applies, by its terms, only to "another prosecution."

33 People v. Tideman, 57 Cal. 2d 574, 581, 370 P.2d 1007, 1011, 21 Cal. Rptr. 207, 211 (1962).

34 All of the counts are submitted to the jury, but a conviction on the greater offense acts as an "acquittal" of the lesser offenses. Id. at 582, 370 P.2d at 1012, 21 Cal. Rptr. at 212.

35 The question of whether the defendant's multiple crimes resulted from a divisible transaction is one of law when there is no conflict in the evidence as to the defendant's actions at the time of the crime. Neal v. State, 55 Cal. 2d 11, 17, 357 P.2d 839, 842, 9 Cal. Rptr. 607, 610 (1960).

${ }^{36} \mathrm{~A}$ detailed discussion of the cases on this subject may be found in Comment, 32 So. CAL. L. REv. 50 (1958).

3735 Cal. 2d 175, 217 P.2d 1 (1950). See Note, 24 So. CaL. L. Rev. 310 (1951).

38 Kidnapping is another one of the crimes which frequently is the basis of multiple punishment and multiple prosecution litigation. See note 7 supra. This is because of the fact that California courts have held that the crime of kidnapping requires only a very brief asportation. People v. Chessman, 38 Cal.2d 166, 192, 238 P.2d 1001, 1017 (1951), cert. denied, 343 U.S. 915, rehearing denied, 343 U.S. 937 (1952) (victim forced to move only twenty-two feet); People v. O'Farrell, 161 Cal. App. 2d 13, 22, 325 P.2d 1002, 1007 (1958); People v. Thwaits, 101 Cal. App. 2d 674, 676-77, 226 P.2d 58, 60 (1951). For a strong criticism of the California position, see People v. Knowles, 35 Cal. 2d 175, 189, 217 P.2d 1, 9 (1950) (Edwards, J., dissenting). 
lesser crime, the robbery, was reversed. ${ }^{39}$ People $v . K y n e t t e^{40}$ involved the placing of a bomb in the victim's automobile. The defendant was given consecutive sentences for attempted murder and the malicious use of explosives. The reviewing court concluded that the use of explosives was only the means for perpetrating the attempted murder, that both convictions were thus based on one physical act, and therefore only one of the convictions could stand. ${ }^{41}$

Several cases ${ }^{42}$ have arisen involving prosecutions for abortion and for murder resulting from the death of the victim. The courts at first took the position that in such a case each charge was based on a separate act. ${ }^{43}$ This stand was reversed, however, in People v. Brown, ${ }^{44}$ in which it was held that a transaction producing a miscarriage was a single act and could not support convictions for two crimes. ${ }^{45}$ A similar result was reached in People v. Logan ${ }^{46}$ in which the defendant knocked his victim unconscious with a baseball bat and then stole her purse. The court considered this to be a single indivisible transaction ${ }^{47}$ and held that the act of inflicting force with the bat could not both be punished as an assault with a deadly weapon and availed of as the force necessary to constitute one of the elements of the crime of robbery. ${ }^{48}$ Thus in each of these cases the courts found only one act within the meaning of section $654 .^{49}$

\section{What Constitutes Multiple Acts}

In In re Chapman ${ }^{50}$ the court found a divisible transaction on a set of facts deceptively similar to those in the Logan case. Chapman pulled a gun on his victim and ordered him to hand over his wallet. When the victim started to run away, the defendant hit him over the head with the gun. Noting that the assault occurred after the robbery had been completed, the court held that the defendant was guilty of two punishable acts.51 People v. Camodeca ${ }^{52}$ presents an example of two distinct, though related, acts. Defendant tried to get a sum of money from

39 People v. Knowles, 35 Cal. 2d 175, 189, 217 P.2d 1, 9 (1950). Accord, People v. Thwaits, 101 Cal. App. 2d 674, 677, 226 P.2d 58, 60 (1951).

4015 Cal. 2d 731, 104 P.2d 794 (1940).

41 Id. at 762,104 P.2d at 810.

42 People v. Tideman, 57 Cal. 2d 574, 370 P.2d 1007, 21 Cal. Rptr. 207 (1962); People v. Brown, 49 Cal.2d 577, 320 P.2d 5 (1958); People v. Powell, 34 Cal. 2d 196, 208 P.2d 974 (1949); People v. Coltrin, 5 Cal.2d 649, 55 P.2d 1161 (1936); People v. Emory, 192 Cal. App. 2d 814, 13 Cal. Rptr. 889 (1961) ; People v. Gomez, 41 Cal. App. 2d 249, 106 P.2d 214 (1940).

43 People v. Coltrin, 5 Cal. 2d 649, 661, 55 P.2d 1161, 1167 (1936).

4449 Cal. 2d 577, 320 P.2d 5 (1958).

45 Id. at $593,320 \mathrm{P} .2 \mathrm{~d}$ at 15.

4641 Cal. 2d 279, 260 P.2d 20 (1953).

47 Id. at 290,260 P.2d at 26.

48 Ibid.

49 See also People v. Kehoe, 33 Cal. 2d 711, 204 P.2d 321 (1949) (grand theft of an auto and driving without the owner's consent held to be one act); People v. McCree, $128 \mathrm{Cal}$. App. 2d 196, 275 P.2d 95 (1954) (defendant set fire to jail; held, defendant could not be punished for arson, and willful and intentional destruction of a public jail or place of confinement, since both arose out of the same act); People v. Branch, 119 Cal. App.2d 490, 260 P.2d 27 (1953) (conviction for possession of marijuana and offering to sell marijuana based on the same act).

5043 Cal. 2d 385, 273 P.2d 817 (1954). See Note, 28 So. CaL. L. REv. 321 (1955).

5143 Cal. at 390,273 P.2d at 819.

3252 Cal. 2d 142, 338 P.2d 903 (1959). 
$M$ by falsely representing to him that certain charges on file against his business could be "fixed" with a state board. When $M$ resisted, defendant attempted to extort the money from him by veiled threats of injury to his person or his business. Convictions for both attempt to commit grand theft and for attempt to commit extortion were affirmed, the court holding that a separate and distinct act had been established as the basis of each conviction. ${ }^{53}$

\section{Neal and the "Intent and Objective" Test}

With this background ${ }^{54}$ of case law the California Supreme Court, in Neal v. State, ${ }^{55}$ set down the guiding principle to be followed in determining the divisibility of an act. In the $N e a l$ case defendant threw gasoline into the bedroom of Mr. and Mrs. $R$ and ignited it. He was convicted on one count of arson and two counts of attempted murder. With regard to the crimes of arson and murder, the court held that both arose out of the same act. ${ }^{56}$ The arson was the means of perpetrating the attempted murder just as the malicious use of explosives was the means of perpetrating the attempted murder in People v. Kynette ${ }^{57}$ and the assault with the baseball bat was the means of commiting the robbery in People v. Logan. ${ }^{58}$ The court declared that the criterion in each case is "the intent and objective of the actor" and that "if all of the offenses were incident to one objective, the defendant may be punished for any one of such offenses but not for more than one."50

Taken at its face, the $\mathrm{Neal}$ test would appear to present a broader definition of "act" than has heretofore obtained. The rule is presented in Neal after a survey of the leading cases applying 654 and purports to be the abiding principle gleaned from these cases. It is difficult, however, to avoid the conclusion that many of the earlier decisions ${ }^{60}$ are utterly irreconcilable with the new formulation, and it re mains to be seen whether Neal will serve to bring some degree of consistency to this rather chaotic field. ${ }^{61}$

\section{Class II-Some Tentative Conclusions}

It should be apparent from the preceding cases that no concrete rule can be laid down regarding multiple punishment in class II. If the court concludes that the defendant has performed one criminal act, he may be punished for only one

53 Id. at $148-49,338$ P.2d at 907 .

54 See also People v. Thompson, 133 Cal. App. 2d 4, 284 P.2d 39 (1955) (kidnapping and robbery in the same transaction held to be separate acts); People v. Chine, 79 Cal. App. 2d 11, 179 P.2d 89 (1947) (forgery of eight documents at one time in the course of one business transaction authorized conviction and consecutive sentences for each of the eight forgeries); People v. Ayala, 167 Cal. App. 2d 49, 334 P.2d 61 (1959) (conviction for unlawful use of narcotics and unlawful possession of the same narcotics upheld); People v. Bruno, 140 Cal. App. 460, 35 P.2d 39 (1934) (kidnapping and robbery in the same transaction held to be separate acts).

5555 Cal. 2d 11, 357 P.2d 839, 9 Cal. Rptr. 607 (1960).

56 Id. at 20, 357 P.2d at 844,9 Cal. Rptr. at 612.

6715 Cal. 2d 731, 762, 104 P.2d 794, 810 (1940).

5841 Cal. 2d 279, 290, 260 P.2d 20, 26 (1953).

5855 Cal. 2d at 19, 357 P.2d at 843-44, 9 Cal. Rptr. at 611-12.

co E.g., People v. Slobodion, 31 Cal. 2d 555, 191 P.2d 1 (1948); People v. Devlin, 143 Cal. 128, 76 Pac. 900 (1904) ; People v. Macias, 161 Cal. App. 2d 594, 326 P.2d 936 (1958); People v. Loignon, 160 Cal. App. 2d 412, 325 P.2d 541 (1958); People v. Freedman, 111 Cal. App. 2d 611,245 P.2d 45 (1952).

61 This formulation has been criticized by one nnember of the Supreme Court. See Seiterle v. Superior Court, 57 Cal. 397, 403, 369 P.2d 697, 700-01, 20 Cal. Rptr. 1, 5 (1962) (Schauer, $\mathrm{J}$., concurring and dissenting). 
of the offenses arising out of that act. If there is a conflict in the evidence as to the defendant's actions, the issue must be submitted to the jury..$^{62}$ When there is no dispute, however, the question of single or multiple acts is one of law for the trial court and may be reviewed on appeal or by habeas corpus after the defendant has begun to serve his term. ${ }^{63}$

A court which imposes consecutive sentences for crimes arising out of a single transaction acts in excess of its jurisdiction ${ }^{64}$ and its sentence is subject to collateral attack. ${ }^{65}$ The correct trial procedure is to sentence the defendant for the offense bearing the most severe punishment and to dismiss the other counts on which the defendant has been found, or to which he has pleaded guilty. ${ }^{66}$ When the trial court erroneously convicts the defendant of two offenses arising out of one act, the most common appellate practice is to reverse the conviction for the lesser offense. ${ }^{67}$ Sometimes, however, the sentences are made to run "concurrently," "merged." This seems error, for merged and concurrent sentences are likely to prejudice the defendant both as to the fixing of his term by the Adult Authority ${ }^{70}$ and as to the application of the California habitual criminal statute. ${ }^{71}$

As for multiple prosecutions in class II, the rule again depends on a judicial determination of whether the crimes related in time arise out of the same "act" within the meaning of section 654 . If the court should conclude that they do, and the defendant has been acquitted or convicted and sentenced for one offense, he cannot later be prosecuted for another offense arising out of the same act. It should be noted that neither Penal Code section 1023 nor the constitutional double jeopardy doctrine offers the class II defendant any protection against being tried for one crime and then later being prosecuted for the related crime. Such a result is prevented, however, by section 654 if the first prosecution terminated in an acquittal or conviction and sentence. This is so because a second prosecution would not place the defendant in jeopardy for the same offense or an included offense, ${ }^{72}$ but would subject him to multiple prosecutions for different offenses arising out of a single act. ${ }^{73}$

\section{Class III-One Act Which Results in Injury to Two or More Persons}

Frequently one physical act causes injury to a number of persons. For example, one burst of machine-gun fire may result in the murder of $A, B$, and $C$ plus an

62 In re Chapman, 43 Cal. 2d 385, 390, 273 P.2d 817, 320 (1954).

63 Neal v. State, 55 Cal. 2d 11, 17, 357 P.2d 839, 845, 9 Cal. Rptr. 607, 613 (1960).

64 Id. at 21,357 P.2d at 845,9 Cal. Rptr. at 613 .

65 Id. at 16, 357 P.2d at 841, 9 Cal. Rptr. at 609.

66 People v. Tideman, 57 Cal. 574, 577, 370 P.2d 1007, 1008, 21 Cal. Rptr. 207, 208 (1962).

67 People v. Chessman, 52 Cal. 2d 477, 496, 341 P.2d 679, 697 (1959) ; People v. Logan,

41 Cal. 2d 279, 290-91, 260 P.2d 20, 27 (1953); People v. Knowles, 35 Cal. 2d 175, 189, 217

P.2d 1, 9 (1950) ; People v. Branch, 119 Cal. App. 2d 490, 496, 260 P.2d 27, 31 (1953).

68 People v. Kynette, 15 Cal. 2d 731, 762, 104 P.2d 794, 810 (1940); People v. Thompson,

133 Cal. App. 2d 4, 10, 284 P.2d 39, 43 (1955).

69 People v. Craig, 17 Cal. 2d 453, 459, 110 P.2d 403, 405 (1941).

70 People v. Brown, 49 Cal.2d 577, 593, 320 P.2d 5, 15 (1958); People v. Branch, 119 Cal. App. 2d 490, 496, 260 P.2d 27, 30 (1953). But see People v. Thompson, 133 Cal. App. 2d 4, 10,284 P.2d 39, 43 (1955), where it is said that the defendant could not be prejudiced by dual convictions if the two sentences were made to run concurrently.

71 CAL. PEN. CODE $§ 644$.

72 Cal. Pen. Code $\$ 1023$.

73 CAL. PEN. CODE § 654. 
assault with intent to commit murder on $D$ and $E$. With regard to double jeopardy in such a situation, California ${ }^{74}$ and some other jurisdictions ${ }^{75}$ take the position that each murder is a separate offense. Thus if a defendant is tried for the murder of $A$, section 1023 does not prevent his later being tried for $B$ 's murder, since he has never been in jeopardy for that offense. This doctrine was established in California in the early case of People v. Majors, ${ }^{76}$ in which the court stated:

[W] have attempted to show that the better rule, and that established by the great weight of respectable authority, is that the murder of two persons, even by the same act, constitutes two offenses, for each of which a separate prosecution will lie, and that a conviction or acquittal in one case does not bar a prosecution im the other.77

This conclusion follows logically if one accepts the premise that each murder is a separate offense. Some states ${ }^{78}$ and the federal courts, ${ }^{79}$ however, hold that the killing is but one crime and cannot be divided. In these states the defendant's plea of former jeopardy in the above example would be sustained. ${ }^{80}$

Even thought the jeopardy doctrine does not avail the defendant in the hypothetical situation, it would seem that Penal Code section 654 would prevent him from being tried consecutively for the various crimes against different victims that arose out of his one act. The opposite conclusion, however, was reached by the court in People v. Brannon. ${ }^{81}$ In that case the defendant had fired one shot at his wife but had missed her and killed a bystander. Defendant was tried for assault with intent to commit murder upon the wife and was acquitted. He was then tried for the murder of the bystander. The trial court refused to accept his plea of former acquittal. The district court of appeal upheld this ruling, stating that section 654 is not applicable where one act has two results, each of which is an act of violence against the person of a separate individual. ${ }^{82}$

The court in the Brannon case did not have to discuss the issue of multiple punishment, since the defendant had been acquitted in the prior trial. This question was unavoidably raised, however, in the $N e a l^{83}$ case. It will be recalled that Neal attempted to murder his victims by throwing gasoline into their bedroom and lighting it. In addition to the arson conviction, discussed above, ${ }^{84}$ he was

74 People v. Majors, 65 Cal. 138, 3 Pac. 597 (1884) ; People v. Brannon, 70 Cal. App. 225, 233 Pac. 88 (1924).

75 Holder v. Fraser, 215 Ark. 67, 219 S.W.2d 625 (1949); Blitch v. Buchanan, 100 Fla. 1242, 132 So. 474 (1931) ; People v. Ciucci, 8 Ill. 2d 619, 137 N.E.2d 40 (1956); Slone v. Commonwealth, 266 Ky. 366, 99 S.W.2d 207 (1936); Berry v. State, 195 Miss. 899, 16 So. 2d 629 (1944).

7065 Cal. 138, 3 Pac. 597 (1884).

77 Id. at $146-47,3$ Pac. at 603 .

78 Hurst v. State, 24 Ala. App. 47, 129 So. 714 (1930); Ruffin v. State, 29 Ga. App. 214, 114 S.E. 581 (1922); State v. Wheelock, 216 Iowa 1428, 250 N.W. 617 (1933); Crocker v. State, 204 Tenn. 615, 325 S.W.2d 234 (1959) ; Spannell v. State, 83 Tex. Crim. 418, 203 S.W. 357 (1918); State v. Houchins, 102 W. Va. 169, 134 S.E. 740 (1926).

79 Ladner v. United States, 358 U.S. 169 (1958); Bell v. United States, 349 U.S. 81 (1955). ${ }^{80}$ Since the double jeopardy prohibition of the fifth anendment of the United States Constitution is not enforceable against the states by way of the fourteenth anendment, Palko v. Connecticut, 302 U.S. 319,328 (1937), each state is at biberty to define double jeopardy differently.

8170 Cal. App. 225, 233 Pac. 88 (1924).

82 Id. at 235-36, 233 Pac. at 92.

8355 Cal. 2d 11, 327 P.2d 839, 9 Cal. Rptr. 607 (1960).

81 See text accompanying notes 56-59 supra. This case combines the class II and class III situations. 
convicted of two counts of attempted murder, the sentences to run consecutively. Affirming the consecutive sentences, the California Supreme Court held that the defendant could be punished for both attempted murders. ${ }^{85} \mathrm{Mr}$. Justice Traynor explained the court's position:

The purpose of the protection against multiple punishment is to insure that the defendant's punishment will be commensurate with his criminal liability. A defendant who commits an act of violence with the intent to harm more than one person or by a means likely to cause harm to several persons is more culpable than a defendant who harms only one person. 86

Although Justice Traynor clarified one aspect of the Brannon decision, he raised doubt as to the validity of the actual holding of that case by cautioning:

\begin{abstract}
Since petitioner was tried for both crimes at the same time we do not decide whether section 654 requires all of the prosecutions to be brought at the same time. Section 654 's preclusion of multiple prosecution is separate and distinct from its preclusion of multiple punishment. The rule against multiple prosecutions is a procedural safeguard against harassment and is not necessarily related to the punishment to be imposed; double prosecution may be precluded even when double punishment is permissible. 87
\end{abstract}

It is difficult to determine the full implication of this statement. Inasmuch as Brannon had been tried twice, the question of whether Neal could have been subjected to multiple trials was presumably not an open one in this state. Furthermore, the Brannon decision is quoted with apparent approval in the Neal opinion. ${ }^{88}$ But if the dictum quoted above, and particularly the italicized portion, were taken literally, it would certainly weaken Brannon as a precedent and indeed, if followed, would represent a new point of departure in this area. California courts, when dealing with section 654 , have always gone on the tacit assumption that if the defendant can be punished for two offenses, he can also be tried separately. This seemed reasonable since both prohibitions ${ }^{80}$ are combined in one sentence of the statute and the criterion ${ }^{90}$ for both is the same.

The $\mathrm{Neal}$ dictum is broad enough to raise questions regarding the conclusions reached in dealing with the class II cases also. If there is a stronger public policy bias against multiple trials than against consecutive sentencing, one would expect two definitions of the word "act" in Penal Code section 654: a broad one for multiple prosecution situations and a more limited one in a multiple punishment context. So far, however, courts have cited cases dealing with these problems interchangeably. Indeed, the dictum in Neal was apparently disregarded in the subsequent case of Seiterle v. Superior Court. ${ }^{91}$ The problem in that case was one of subsequent prosecution; ${ }^{02}$ in order to resolve the issue the court went directly to the standard laid down in the $\mathrm{Neal}$ case where, it will be remembered,

85 Neal v. State, 55 Cal. 2d 11, 21, 357 P.2d 839, 844, 9 Cal. Rptr. 607, 612 (1960).

86 Id. at 20,357 P.2d at 844,9 Cal. Rptr. at 612.

87 Id. at 21, 357 P.2d at 844-45, 9 Cal. Rptr. at 612-13. (Emphasis added.)

88 Id. at $20-21,357$ P.2d at 844,9 Cal. Rptr. at 612 .

80 I.e., the prohibitions against multiple prosecution and against multiple punishment.

00 "An act or omission which is made punishable in different ways ..." CAL. PEN. CODE $\S 654$.

9157 Cal. 2d 397, 369 P.2d 6, 20 Cal. Rptr. 1 (1962).

92 Id. at 399,369 P.2d at 698,20 Cal. Rptr. at 2. 
the question of multiple prosecutions was not in issue and was specifically reserved by the court. ${ }^{93}$

One can only wait to see whether any of the developments suggested by the dictum in $\mathrm{Neal}$ will come to pass. Meanwhile the rule as to class III cases is that even if there is unquestionably only a single physical act, separate trials and consecutive sentences are permitted for each offense arising out of the act if the offenses represent injuries to different victims. Such a conclusion is consistent with the wording of section 654 in those cases where the defendant's act produces a series of the same crimes, e.g., murdering $A$ and $B$ with one shot. This is because 654 applies only to an act made punishable in different ways by different provisions of the Penal Code - two murders naturally are made punishable by the same provision of the code. But one cannot avoid the conclusion that in a case such as People v. Brannon, ${ }^{94}$ where the defendant's act results in the murder of $A$ and an assault on $B$, the courts, in effect, refuse to apply section 654 even though the situation involves different code provisions and thus seems to fall directly within its language.

One might suppose that successive trials for what is, practically speaking, the same crime would be a violation by the state of the due process clause of the fourteenth amendment. The United States Supreme Court, in two cases ${ }^{95}$ decided the same day, refused to so hold. One of the cases, Ciucci v. Illinois, ${ }^{98}$ is perhaps the most shocking example of multiple trials on record. Defendant was tried three times for the murder of various members of his family, all of whom were found dead in a burning building. At the first two trials the juries brought in verdicts of guilty and fixed the penalty at twenty and forty-five years imprisonment respectively. At a third trial defendant was sentenced to death. In each trial exactly the same evidence was introduced; the accused was tried each time, in the words of Justice Douglas' dissent, "in form for one murder, in substance for four." ${ }^{97}$ There has never been in California such an extreme case of multiple prosecutions as occurred in Ciucci v. Illinois. ${ }^{98}$ Nevertheless, under the reasoning of People $v$. Brannon, ${ }^{99}$ such a procedure would be legal, section 654 notwithstanding. ${ }^{100}$

93 Neal v. State, 55 Cal. 2d 11, 21, 357 P.2d 839, 844, 9 Cal. Rptr. 607, 612 (1960).

9470 Cal. App. 225, 233 Pac. 88 (1924).

95 Hoag v. New Jersey, 356 U.S. 464 (1958); Ciucci v. Illinois, 356 U.S. 571 (1958).

88356 U.S. 571 (1958).

97356 U.S. at 574.

98 See also Hoag $r$ New Jersey, 356 U.S. 464 (1958). Defendant allegedly robbed four persons in a tavern loold-up. At the $\hat{n}$ 'st trial he was acquitted of robbing $A, B$, and $C$. He was then indicted for the robbery of $D$ and on the same evidence used at the first trial was convicted. The United States Supreme Court affirmed the conviction, declaring: "We do not think that the Fourteenth Amendment always iorbids States to prosecute different offenses at consecutive trials even though they arise out oi the same occurrence." Id. at 467 .

9970 Cal. App. 225, 233 Pac. 88 (1924)

100 The situation where a single act produres offenses punishable by several jurisdictions is covered by CAL. PEN. CODE $\S 656$ :

Whenever on the trial of an a a used person it appears that upon a criminal prosecution under the laws of another State, Government, or country, founded upon the act or omission in respect to which he is on trial, he has been acquitted or convicted, it is a sufficient defense.

This section purports to extend the protections against multiple punishments and multiple prosecutions to those situations where the prior prosecution was in a federal court or another state or country. The standards of 656 ("act or omission" and "acquitted or convicted") are 


\section{CONCLUSION}

Though reference has been made to the trio of problems presented by multiple prosecutions, double jeopardy, and multiple punishment, it is submitted that the cases themselves present only two basic questions. These are, first, to what extent can a defendant be made twice to stand trial for conduct arising from a single unlawful act, and second, to what types of antisocial acts should the law apply the added sanction of punishment by way of consecutive prison sentences?

The prohibitions against double jeopardy and multiple prosecutions both address themselves to the first of these questions. The former is an ancient doctrine ${ }^{\mathbf{1 0 1}}$ universally accepted in the United States and the other common law jurisdictions; ${ }^{102}$ the latter, a more recent doctrine, exists only in California and one other state. ${ }^{103}$ Brought together in the same code, they present a patchwork remedy to a problem which demands and deserves a more carefully worked out solution. ${ }^{104}$

As to the question of consecutive sentencing, the best answer advanced so far appears to be that given by Justice Traynor in the Neal case: the defendant who injures or endangers two persons is twice as culpable as the defendant whose con-

essentially the same as those at 654 and the above analysis of 654 should apply to this statute. In the only reported case dealing directly with $\$ 656$, People v. Candelaria, $153 \mathrm{Cal}$. App. 2d 879,315 P.2d 386 (1957), the district court of appeal refused to apply it to a situation which appeared to be clearly within its terms. In that case the defendant entered a bank and forced a teller to hand over all the cash she could obtain. He was tried and convicted in federal court for robbery of a national bank (18 U.S.C. $\$ 2113$ (1958)) and sentenced to federal prison. He was later tried and convicted in a California court for robbery. This conviction was reversed as being in violation of CAL. PEN. CODE $\S 656$. He was then charged with the crime of burglary, the facts to support the charge heing the same as those presented at the robbery trial. Defendant's conviction for burglary was upheld on the ground that the act of entering the bank to commit a felony was distinct from his act of robbing the teller. Id. at 884,315 P.2d at 389 . It is doubtful whether this case will be followed, inasmuch as the California Supreme Court in People v. Brown, supra note 44, and Neal v. State, supra note 55, has subsequently adopted a broader interpretation of the word "act" in the analogous statute, CAL. PEN. CODE $\$ 654$. Under the test set down in Neal it would appear that the defendant's entry into the bank was incidental to his objective of robbery and therefore part of a single indivisible transaction. See also CAL. PEN. CODE $\S 793$ : "Where an act charged as a public offense is within the jurisdiction of another State or country, as well as of this State, a conviction or acquittal thereof in the former is a bar to the prosecution or indictment therefor in this State." This statute is couched in terms of an "act charged as a public offense" and thus seems more narrow than $\S 656$, which refers to multiple prosecutions founded upon the same act or omission.

101 Mullins v. Commonwealth, 258 Ky. S29, 530, 80 S.W.2d 606, 607 (1935): "This [double jeopardy provision of the Kentucky Bill of Rights] expresses a doctrime so ancient that it is impossible to trace its origin. It seems always to bave been imbedded in every system of jurisprudence, as it is 'a part of the universal law of reason, justice, and conscience."

102 Ex parte Lange, 85 U.S. 163,168 (1873).

103 New York is the only other state which has a similar statute. People v. Repola, 280 App. Div. 735, 739, 117 N.Y.S.2d 283, 288 (1952). See N.Y. Pen. Law § 1938.

104 Indicative of the general confusion in this field is the statement of petitioner in Seiterle v. Superior Court, 57 Cal. 397, 369 P.2d 697, 29 Cal. Rptr. 1 (1962), that he was being subjected to "double prosecution and double punishment for the same act in violation of his constitutional rights forbidding double jeopardy." Id. at 398, 369 P.2d at 697, 20 Cal. Rptr. at 1. There was clearly no issue of double punishment in the case since the defendant's only contention was that having been convicted and sentenced for kidapping, he could not now be tried for the murder which arose out of the same act of kidnapping. In any event, since one of the threatened punishments was death, there could be no question of multiple punishment in the case. This is pointed out in the concurring and dissenting opinion of Mr. Justice Schaucr. Id. at 405,369 P.2d at 702, 20 Cal. Rptr. at 6. 
duct results in injury or danger to only one. ${ }^{105}$ It would seem that there is sound moral and practical justification for allowing consecutive sentences when there are multiple victims. One may doubt, however, that there is such justification for allowing a separate trial for each offense in such cases. The procedure that was permitted in Ciucci v. Illinois ${ }^{106}$ amounts to a needless harassing of the defendant with successive trials until a verdict is returned which meets with the prosecutor's approval.

Undoubtedly few prosecutors would defend the use of multiple prosecution in the Ciucci case. Nevertheless, many would maintain that giving the state a second chance to convict the defendant can at times serve a useful purpose by preventing the injustice that would otherwise result from the rule that the prosecution has no right to appeal. ${ }^{107}$ Thus under the present system, if the defendant is acquitted due to an erroneous ruling by the court, or because the jury was subjected to undue influence, or as a result of other irregularities, he cannot be retried for the same offense no matter how faulty the first trial might have been. ${ }^{108} \mathrm{~A}$ criminal sustaining such a windfall does not, however, go free if the state can mould the elements of his conduct into a different offense or can charge the same offense against a different victim. Hence the use of multiple prosecution in this situation produces a desirable result similar to that which could have been obtained by a reversal and a retrial.

In spite of any possible beneficial aspects, it is suggested that the device of multiple prosecutions-especially when left up to the judgment and good faith of the prosecutor-lends itself too readily to abuse and therefore should be prohibited. One step in this direction would be an overruling of the Brannon case and an interpretation of section 654 so as to prohibit successive trials where one act results in injury to more than one person.

A more complete solution to the multiple prosecution-multiple punishment dilemma, however, requires remedial legislation. Such legislation might well be based on the notion advanced in $\mathrm{Neal}$ that multiple prosecution may be precluded even when multiple punishment is not; ${ }^{109}$ this would require that the two issues be dealt with in separate code sections. ${ }^{110}$ For example, multiple punishment might be prohibited for offenses against the same victim arising out of a single act. Multiple prosecutions, on the other hand, might be prohibited for offenses having their origin in the same transaction regardless of the number of victims. ${ }^{111}$ Under such a scheme consecutive sentencing would be allowed where a criminal transaction involved two or more distinct crimes or where the transaction caused injury to multiple victims. But acquittal or conviction for any one of the offenses arising out of this transaction would be a bar to a later prosecution for any of the other offenses even though all crimes could have been punished with consecutive sentences had they been tried together.

Arnold D. Kahn

105 See note 86 supra and accompanying text.

106356 U.S. 571 (1958).

107 People v. Webb, 38 Cal. 467 (1869).

108 People v. Terrill, 132 Cal. 497, 64 Pac. 894 (1901); People v. Roberts, 114 Cal. 67, 45 Pac. 1016 (1896); People v. Horn, 70 Cal. 17, 11 Pac. 470 (1886); People v. Morris, 115 Cal. App. 2d 585, 252 P.2d 681 (1953).

109 See text accompanying note 87 supra.

110 Model Penal Code $\$ 7.06$ (Tent. Draft No. 2, 1956) prohibits multiple punishment while multiple prosecution is dealt with in MODEL PENAL CODE \$\$ 1.08-1.12 (Tent. Draft No. 5,1956$)$.

111 One way to achieve this result is to require the joinder of all offenses based on the same conduct. The Model Penal Code has such a provision. Model Penal Code $\$$ 1.08-1.12 (Tent. Draft. No. 5, 1956). 